\title{
La enfermedad de los caballos locos
}

\author{
Walter Ledermann
}

${ }^{1}$ Centro de Estudios Humanistas Julio Prado.

Recibido: 16 de noviembre de 2018

Correspondencia a: Walter Ledermann oncemayor@gmail.com

\section{Crazy horse disease}

With the apparition of the crazy cows disease at the end of twentieth century, great was the temptation for denominate "crazy horses disease" an ancient enzootic encephalo-myelitis, known from the $17^{\text {th }}$ century and now named "Borna disease" in 1970, because severe outbreaks affecting horses in this city of Germany since 1885. But the sickness was not a prion disease but a viral one, causing also encephalopathy in several other animal species. After seventy years of investigation, the finding of the virus in human patients with psychiatric pathology in the eighties gave an incentive to work harder, and the genome structure of the so called Bornavirus was completely described. Recently, japanese investigators found that elements homologous to the nucleoprotein $(\mathrm{N})$ gene of Bornavirus exist in the genomes of several mammalian species, including humans, in which these sequences have been designated endogenous Borna-like N (EBLN) elements. And now the question is what they are doing there since their integration two million years ago.

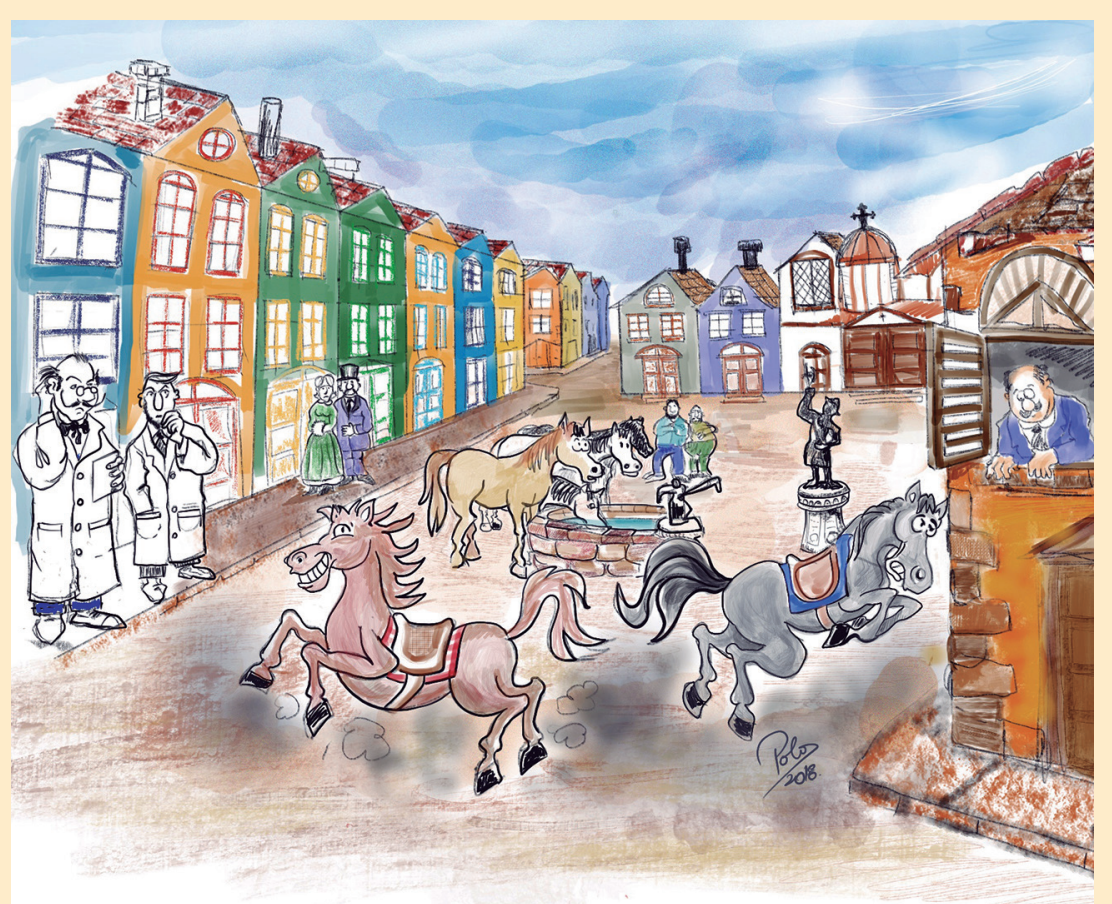

Vacas locas, pero caballos no<smiles>C1CC2CC(C1)CC1CCC1C2</smiles>
uando apareció la enfermedad de las vacas locas, surgió la tentación de hablar también de la “enfermedad de los caballos locos", pero ésta no es una encefalitis espongiforme causada por un prion, sino una de carácter infeccioso, causada por el virus Borna, que afecta no sólo a los equinos sino a varias especies de animales.
Lejos de ser una nueva patología, ya era conocida en Alemania al menos desde 1660, cuando se describiera un mal que afectaba a los caballos, caracterizado por un dolor tan intenso que los volvía "estúpidos e insensibles". Hay también registros en 1716 agregando que los animales, aquejados de cefalea (¿algún caballo lo dijo?), presentaban insomnio, melancolía y agitación. Por último, en 1822 se publicó una detallada descripción de la inflamación cerebral presente en caballos fallecidos a causa de esta enfermedad. Aunque la enfermedad era endémica en vastas zonas de Alemania y Austria, la ciudad de Borna le daría su nombre definitivo, a causa de un gran brote aparecido en ella, durante el cual los caballos se movían en círculos, completamente atontados, episodio que algunos datan en 1885 y otros en $1920^{1}$.

Así pues, en el mundo de las ciencias médicas el pintoresco nombre no prevaleció sobre Bornasche Krankheit (BVD, Borna Virus Disease, enfermedad por Bornavirus) adoptado en 1970, y si usted, amable lector, busca en Google "caballos locos", le aparecerá de inmediato el Gran Jefe Caballo Loco (Crazy Horse), quien en compañía de su aliado Toro Sentado (Sitting Bull) infligieron una terrible derrota al Coronel Custer en Little Big Horn (curioso nombre este contradictorio "Pequeño Gran Cuerno", un oxímoron, como dirían los infaltables siúticos que escriben en la prensa). En nuestra juventud escuchamos muchas veces a Rose Maddox, artista country de buen vozarrón, cantar con furia una canción sobre esta célebre batalla, cuyo estribillo, que se repetía una y otra vez sobre un fondo de alaridos indígenas, anunciaba la desproporción de las fuerzas y la inevitable derrota de Custer: 
Three thousand Indian painted for war

Company B has two sixty four

No one the help

No one the hope

When Custer fights the battle of Little Big Horn...

Pero dejemos la guerra y la música para volver atrás, muy atrás en el tiempo, a la plaza de la ciudad de Borna en 1885 , cuando los caballos enloquecieron y comenzaron a girar ciegamente en círculos, para estupor y espanto de los apacibles burgueses que tomaban el sol. La enfermedad se expandió en un santiamén, los pobres animales, como burros de noria, repetían sus locos giros, cruzaban sus patas, abatían sus cuellos y se estrellaban contra los muros, siendo fuerza tener que sacrificar dos mil de estas desdichadas bestias.

\section{En las patas de los caballos}

Dos científicos alemanes, E. Joest y W. Zwick, unos caballeros que en las viejas fotografías aparecen con tiesos cuellos blancos y bigotes en punta, motivados por el episodio de la plaza de Borna se metieron, literalmente, en las patas de los caballos, desoyendo la advertencia que de niños nos hacían nuestros mayores en orden a evitarnos problemas, para investigar en el terreno este curioso fenómeno. Sobre sus sobrias tenidas se pusieron blancos delantales, cerrados hasta el cuello; enfundaron sus manos en guantes de goma y sus pies en altas botas de cuero y, montados en briosos caballos, fueron a recoger las muestras y a buscar las evidencias a lo largo y ancho de los campos de Sajonia, viajando y publicando durante veinte años.

La enfermedad había sido siempre -y lo sigue siendoendémica en dicho antiguo reino, donde está Borna, pero también en Bavaria, Baden-Württemberg, Hesse, Suiza y regiones alpinas de Austria, de manera que ambos sabios debieron viajar mucho, alternando sus investigaciones en el terreno y en el laboratorio, logrando adaptar al entonces invisible virus a los conejos y cultivarlo en ratas y en ratones, permitiendo una vacunación con un extracto de sus enfermos cerebros ${ }^{2-5}$.

Pero los avances más notables vinieron con la identificación del virus y la aplicación de las modernas técnicas de biología molecular a la investigación, gracias a lo cual sabemos ahora que hay hasta $20 \%$ de caballos infectados en Alemania, de los cuales una pequeña parte enferma y de ésta no todos mueren, siendo el curso fatal descrito en el episodio de Borna más bien raro. Sucesivas investigaciones, iniciadas por Lipkin en 1990 describiendo las primeras huellas genéticas del virus, seguidas por las efectuadas por Bode y De La Torre, culminaron con la completa secuenciación del virus en $1996^{6,7}$. Pero el avance de la ciencia suele traer complicaciones y habían comenzado a aparecer algunas noticias alarmantes.

\section{EI Bornavirus ataca al hombre}

Se sabía ya que este virus también afectaba a ovejas, gatos, monos, avestruces y quizás cuántas criaturas más, uniéndose a receptores cerebrales en la zona del hipocampo y del hipotálamo, provocando apatía, alteraciones de conducta y hasta de hábitos sexuales. En suma, otra zoonosis viral, no transmisible al hombre, que habría pasado a un definitivo segundo plano si no fuera porque en 1988 un artículo en Lancet narraba el hallazgo por científicos alemanes de anticuerpos específicos para Bornavirus en pacientes con desórdenes mentales infectados por $\mathrm{VIH}^{8}$. Los mismos investigadores, encabezados por Bode, tras una década de trabajo continuo, llegaron a estremecedoras conclusiones, al encontrar en la sangre de pacientes que sufrían de depresión proteínas del virus Borna y también trazas de ARN, afirmando que más de $50 \%$ de los casos de depresión pudieran ser causados por el virus, que luego lograrían aislar de la sangre de los enfermos para inocularlo en conejos, animales que también enfermaron, languideciendo y encogiéndose de pena ${ }^{9,10}$.

La amenaza creció al establecerse poco después la secuencia total del genoma viral y determinarse que era sensible a la amantadina, antimicrobiano usado clásicamente para tratar la influenza y también... jel Parkinson! ${ }^{11}$. Entonces... ¿por qué no probarlo en el tratamiento de la depresión? Se probó en pacientes bipolares y mejoraron, desapareciendo los síntomas clínicos y los virus de la sangre. Se encendió la polémica, que persiste hasta hoy.

Cualquier niño de mente curiosa que se meta a internet y busque "Bornavirus" se encontrará con noticias contradictorias como estas:

En el año 2012 un equipo de investigadores de la Universidad de Columbia, luego de una ardua investigación que acaba de finalizar en enero, niega por completo la posibilidad de que este virus sea responsable de enfermedades mentales como esquizofrenia, trastorno bipolar o depresión grave, desmintiendo otra publicación de un grupo de cientificos japoneses de la Universidad de Osaka.

Los cientificos norteamericanos estudiaron un grupo de 189 pacientes portadores de males como esquizofrenia, trastorno bipolar, trastorno depresivo mayor, por supuesto que con un adecuado grupo control de individuos sanos del mismo sexo, edad, región y estatus socioeconómico, tomando a enfermos y controles muestras de sangre en busca del material genético del virus para realizar pruebas de nivel molecular.

El resultado demostró que no había ningún dato que indicara un aumento de carga viral o de anticuerpos 
durante el periodo de episodios psiquiátricos, ni se encontraron evidencias de infección activa o histórica en cualquiera de los sujetos.

W. Ian Lipkin, del Centro de Infección e Inmunidad, señala que el estudio se centró en la preocupación de que las técnicas clásicas no permitían conocer el verdadero papel del Bornavirus en las enfermedades mentales estudiadas, para corregir lo cual los autores desarrollaron un método de investigación a nivel molecular.

El trabajo se efectuó en colaboración de otras siete instituciones en Estados Unidos, Alemania y Australia, y sus resultados se publicaron en la revista "Molecular Psychiatry" 12 .

Al mismo tiempo nuestro agudo e hipotético lector encontrará estudios japoneses de la Universidad de Osaka, que culminan en el año 2003 al encontrar una relación entre una proteína del virus de la enfermedad de Borna, y la aparición de síntomas de enfermedad mental en ratones. "Tras insertar el gen de una sola proteína del virus Borna en embriones de ratones, vimos que, a medida que los ratones crecían, la proteína del virus se expresaba en las células gliales del cerebro, como ocurre con la esquizofrenia", señalaron los científicos. Estos ratones desarrollaron anomalías en su comportamiento, tales como agresividad y funciones cognitivas y neurológicas alteradas $^{13,14}$.

La mayor parte de la comunidad científica ha considerado que la investigación norteamericana ha puesto fin a la discusión y el que el virus Borna no afecta a los humanos: la mayor parte, pero no toda.

\section{Genes del Bornavirus presentes en el genoma humano}

Keizo Tomonaga, defensor de la participación del virus en la esquizofrenia, es un japonés tenaz y no ha dejado de estudiar la relación del Borna con los humanos, hasta encontrar que en nuestro genoma hay genes de este odioso virus.

Como es sabido, en 1990 se inició un ambicioso proyecto para conocer el genoma humano en su totalidad, es decir, cuántos son los genes que constituyen nuestro patrimonio hereditario, en qué orden están dispuestos en los cromosomas, qué funciones tienen, cómo colaboran entre sí, etc. En suma, la idea era confeccionar un mapa con los veinte mil a veinticinco genes que tenemos, lo que todos los ignorantes, al ser entrevistados en la televisión, llaman "mi ADN".

El Departamento de Energía de EE.UU. y los Institutos Nacionales de dicha nación encargaron la tarea a un grupo de investigadores, que encabezaría el doctor Francis Collins, con un presupuesto de tres mil millones de dólares y un plazo de quince años. Como mucha gente le puso el hombro y colaboró y como la tecnología fue avanzando muy rápido, especialmente en el aspecto computacional, la tarea se cumplió antes, en el año 2000. El 26 de junio de 2000 los gobernantes de EE.UU. y del UK, Bill Clinton y Tony Blair, anunciaron que estaba listo el "borrador", cuya su versión final y "pasada en limpio" se lanzaría en el $2003^{15}$.

En términos generales, puede definirse este genoma como la secuencia total de su ácido desoxirribonucleico, conocido por la sigla ADN. Está fragmentado en 23 pares de cromosomas separados, con un total estimado entre 22.500 y 25.000 genes distintos, que codifican la receta para hacer las múltiples proteínas de nuestro organismo. Cada persona tiene un genoma distinto y único, como la huella digital, salvo los gemelos y los clones.

La continuación lógica del proyecto genoma humano es el proyecto microbioma humano, que considera nuestros genes y el de las bacterias que viven felizmente dentro de nosotros, en comunidad, contribuyendo a nuestra economía y desarrollo. Entiéndase que no todos estos genes microbianos están al interior de nuestros cromosomas, habiendo demostrado ya el borrador del año 2000 que un muy pequeño porcentaje de genes podría tener origen no humano, pero la genética sale cada día con nuevas sorpresas y una publicación en la prestigiosa revista Nature, en enero de 2010, corrobora que $8 \%$ del genoma humano proviene de virus que tienen ARN en lugar de ADN, como los retrovirus y el Bornavirus. ¿Quién dijo tal cosa? Los sabios japoneses, entre los cuales está ya imaginaréis quién: Keizo Tomonaga.

\section{Tora, tora, Tomonaga ataca de nuevo}

La cosa empezó con el japonés Horie buscando en el genoma de 234 células de organismos superiores genes similares a genes del Bornavirus, encontrándolos en varias especies de mamíferos, como el hombre, primates no humanos, elefantes y roedores. Alentado por estos resultados, el grupo de investigadores que acompaña a Keizo Tomonaga ha terminado por encontrar dos genes humanos similares a genes del Borna, que llamó EBLN-1 y EBLN-2, cuya función en el hombre no se conoce. Reconforta, en todo caso, saber que otros genes provenientes de retrovirus injertados en nuestro genoma son beneficiosos, al codificar para la producción de proteínas esenciales para el desarrollo de la placenta ${ }^{16}$.

En su análisis filogenético, trepando a nuestro árbol genealógico, para determinar aproximadamente en qué momento de la evolución estos genes víricos nos incrustaron, los japoneses coinciden con los norteamericanos Gifford y Coffin, fechando la incorporación de estos genes del Bornavirus a nuestro genoma hace unos dos millones de años ${ }^{17,18}$. 
El conocimiento que tenemos de nosotros como especie ha sido un poquito mal interpretado-dijo Gifford-Tratamos de ignorar que nuestro ADN ha evolucionado gracias a la contribución de bacterias y de otros microorganismos, utilizando nuestro sistema inmune esa información para protegernos de la infección.

De la primera de estas frases, harto críptica, científicos de mucha imaginación, y gente alharaca también, han postulado que nuestro código genético pudiera ser muy antiguo, incluso diseñado haces miles de millones de años, habiendo llegado a la Tierra quizás cómo, resucitando así la antigua teoría de la panspermia, que repuntó cuando Francis Crick, el descubridor de la doble espiral de nuestro ADN, sugirió que la vida pudo haber llegado a nuestro mundo en una espora errante desde el espacio exterior ${ }^{19}$.

Mucha especulación, pero la duda que persiste es... ¿por qué, si genes del virus Borna ya existían hace dos millones de años, la enfermedad que produce en los caballos no se observó mucho antes?

Frente este misterio en la evolución hípica, quizás exclamaría Darwin:

- ¡Mira, tú, que no eran los caballos los locos, sino estos científicos!

\section{Resumen}

Con la aparición de la enfermedad de las vacas locas a finales del siglo XX, nació la tentación de llamar enfermedad de los caballos locos a una Antigua enzootia alemana, una encéfalo-mielietis conocida desde el siglo XVII y desde 1970 llamada "enfermedad de Borna", a causa de severos brotes afectando a los caballos en esa ciudad de la Sajonia desde 1885. Como los animales caminaban en círculos, cruzaban las patas, se veían lentos y estúpidos y parecían experimentar fuerte cefalea, algunos observadores ignorantes, entonces y ahora, pudieron pensar que estos caballos estaban locos. Más, no era una encefalitis espongiforme causada por un prion, sino una infección viral que podía afectar a varias especies animales.

Después de setenta años de investigación en busca del agente causal, la aparición de las vacas locas motivó a los investigadores a darse prisa, que se hizo frenética al encontrar el virus en pacientes humanos afectados por diversas patologías psiquiátricas en los años ochenta, hasta llegar a la completa secuenciación del ahora llamado Bornavirus. No terminaba de rechazarse por completo su rol en estas patologías, cuando investigadores japoneses encontraron elementos homólogos al gen de la nucleoproteína $\mathrm{N}$ del virus en el genoma de varias especies de mamíferos, incluyendo la humana. Designadas estas secuencias como elementos endógenos Borna-like $N$ (EBLN), que se habrían integrado a nuestro genoma hace dos millones de años, la pregunta que surge es... ¿qué han estado haciendo allí durante tanto tiempo?

\section{Referencias bibliográficas}

1.- Dürrwald L, Ludwig H. Bornavirus disease (BDV), a (zoonotic?) worldwide pathogen. A review of the history of disease and the virus infection with comprehensive bibliography. Zentralbl Veterinärmed B. 1997; 44 (3):14784.

2.- Ludwig H, Bode L. Borna disease virus: new aspects on infection, disease, diagnosis and epidemiology. Rev Sci Tech 2000; 19 (1): 259-88.

3.- Joest E. Vergleichend-anatomische Betrachtungen über Encephalitis. Klin Wochenschr 1926; 5: 209-11.

4.- Joest E, Degen K. Untersuchungen über die pathologische Histologie, Pathogenese und postmortale Diagnose der seuchenhaften Gehirn Rückenmarksentzündung (Bomaschen Krankheit) des Pferdes. Zeitschr Infektionskr parasit Krank Hyg Haustiere 1911; 9: 1-98.

5.- Zwick W, Seifried O. Übertragbarkeit der seuchenhaften Gehirn- und Rückenmarksentzündung des Pferdes (Boma'schen Krankheit) auf kleine Versuchstiere (Kaninchen). Berl Münch Tierärztl Wochenschr 1925; 41: 129-32.

6.- Lipkin W I, Travis G H, Carbone K M, Wilson M C. Isolation and characterization of Borna disease agent cDNA clones. Proc Natl Acad Sci USA 1990; 87: 4184-8.

7.- De la Torre J C, Bode L, Dürrwald R, Cubitt B, Ludwig H. Sequence characterization of human Borna disease virus. Virus Res 1996; 44 (1): 33-44.

8.- Bode L, Riegel S, Ludwig H, Amsterdam J D, Lange W, Koprowski H. Borna disease virus-specific antibodies in patients with HIV infection and with mental disorders. Lancet 1988; 2 (8612): 689.

9.- Bode L, Dürrwald R, Rantam F A, Ferszt R, Ludwig H. First isolates of infectious human Borna disease virus from patients with mood disorders. Molec Psychiatry 1996; 1 (3): 200-12.

10.- Bode L, Ludwig H. Borna Disease Virus Infection, a Human Mental-Health Risk. Clin Microbiol Rev 2013; 16 (3): 53445.

11.- Bode L, Dietrich D E, Stoyloff R, Emrich H M, Ludwig H. Amantadine and human Borna disease virus in vitro and in vivo in an infected patient with bipolar depression. Lancet 1997; 349 (9046): 178-9.

12.- Hornig M, Briese T, Licinio J, Khabbaz R F, Altshuler L L, Potkin S G, et al. Absence of evidence for bornavirus infection in schizophrenia, bipolar disorder and major depressive disorder. Mol Psychiatry 2012; 17: 486-93. doi:10.1038/mp.2011.179.

13.- Watanabe M, Kobayashi T, Tomonaga K, Ikuta K. Antibodies to Borna disease virus in infected adult rats: an early appearance of anti-p10 antibody and recognition of novel virus-specific proteins in infected animal brain cells. $J$ Vet Med Sci 2000; 62 (7): 775-8.

14.- Kamitani W, Ono E, Yoshino S, Kobayashi T, Ikuta K. Glial expression of Borna disease virus phosphoprotein induces behavioral and neurological abnormalities in transgenic mice. Proc Nati Acad Sci U S A 2003; 100 (15): 8969-74. 
15.- Staff and Agencies. Clinton and Blair hail gene "triumph". The Guardian 2000; Mon 26 June, 16:34 BST.

16.- Horie M, Honda T, Suzuki Y, Kobayashi Y, Daito T, Oshida $\mathrm{T}$, et al. Endogenous non-retroviral RNA virus elements in mammalian genomes. Nature 2010; 463: 84-7. doi: 10.1038/ nature08695.

17.- Katzourakis A, Gifford R J. Endogenous viral elements in animal genomes. PLoS Genet 2010; 6: e1001191. doi: 10.1371/journal.pgen.1001191.
18.- Kobayashi Y, Horie M, Tomonaga K, Suzuki Y. No evidence for natural selection on endogenous Borna-like nucleoprotein elements after the divergence of Old World and New World monkeys. PLoS One_2011; 6(9): e24403. doi: 10.1371/journal.pone.0024403.

19.- Crick F. Life, Its Origin and Nature". Simon and Schuster, 1981. ISBN 0-7088-2235-5 / "Life Itself, Its Origin and Nature”. Simon \& Schuster, 1981. ISBN 0-671-25562-2. 